\title{
RELATIONSHIP BETWEEN DRAINAGE NETWORK AND SEMI-ARID PLANATION SURFACES
}

\author{
relações entre rede de drenagem e superfícies de aplainamento semiáridas \\ Kleber Carvalho Lima * \\ Cenira Maria Lupinacci da Cunha ** \\ Archimedes Perez Filho ***
}

\begin{abstract}
Resumo
Redes de drenagem intermitentes e efêmeras são variáveis importantes no estudo da evolução geomorfológica de superfícies de aplainamento semiáridas, embora sejam pouco pesquisadas na geomorfologia brasileira. Nessa perspectiva, esse artigo propõe analisar as contribuições da rede de drenagem no processo de evolução de superfícies de aplainamento, tendo como método de análise a abordagem sistêmica. Para isso, identificamos os níveis de aplainamento juntamente com as coberturas superficiais e avaliamos o grau de dissecação do relevo com base na compartimentação geomorfológica e nas características dos canais de drenagem. Os resultados demonstraram que os diferentes estados de conservação e dissecação do aplainamento estão relacionados aos processos realizados por regimes fluviais dessa natureza, assim como a elaboração de compartimentos geomorfológicos está relacionado a diferentes padrões espaciais da rede de drenagem.

Palavras-chave: Rede de drenagem; Superfície de aplainamento; Semiárido.

Abstract

Ephemeral and intermittent drainage networks are important factors for the understanding of planation surface evolution in semi-arid areas. Currently, this subject is rarely studied in the Brazilian geomorphological literature. In this paper, we explored this topic and we identified the different levels of planation surface, we analyzed the superficial coverage and the drainage channels characteristics and we analyzed the dissection of landforms. The results showed that the different levels of conservation and dissection of the planation surface is related to the fluvial process, as well as the elaboration of geomorphological compartments is related to different spatial patterns of the drainage network.
\end{abstract}

Key words:Drainage network; Planation surface; Semi-arid.

\begin{abstract}
Resumen
Drenajes fluviales efímeros e intermitentes son variables importantes para la comprensión de la evolución de las superficies de aplanamiento en las zonas semiáridas. Sin embargo, actualmente este tema ha sido poco estudiado en la literatura geomorfológica brasileña. En esta investigación exploramos este tema y hemos identificado los diferentes niveles de la superficie de aplanamiento, analizamos la cobertura superficial y las características de los arroyos y analizamos la disección de las formas del terreno. Los resultados mostraron que los diferentes niveles de conservación y disección de la superficie de aplanamiento son respuestas de los procesos que actúan en los arroyos y la formación de los compartimentos geomorfológicos son respuestas directas de los diferentes patrones espaciales de la red de drenaje.
\end{abstract}

Palabras claves: Red de drenaje; Superficie de aplanamiento; Semiárido.

(*) Master of the Universidade Estadual de Campinas - Rua João Pandiá Calógeras, CEP: 13083870, Campinas (SP), Brasil. Tel: (+55 19) 37884567 - klebercarvalho.two@gmail.com

(**) Lecturer, Dr. of the Universidade Estadual Paulista - Avenida 24A n. 1515, CEP: 13506-900 - Rio Claro (SP), - Brasil. Tel: (+55 19) 35269331 - cenira@rc.unesp.br

(***) Lecturer, Dr. of the Universidade Estadual de Campinas e Bolsista Produtividade do CNPq - Instituto de Geociências, CEP: 13083-970, Campinas (SP), Brasil. Tel: (+55 19) 37884567 - archi@ige.unicamp.br 


\section{INTRODUCTION}

The great planated regions on the terrestrial surface have been widthly researched and as a result classic theories such as Davis' Geographical Cycle (1899), the Theory of Primärrumpf developed by Penk in 1924, King's Theory of Pediplanation of 1953 and Büdel's Theory of Etchplanation in 1957, sought to characterize these surfaces and principally, to explain their genesis and evolution. Based on these theories, studies of Brazilian planated surfaces have had great contributions from authors like King (1956), Ab' Saber (1956), Tricart (1958), Ruellan (1959), Demangeot (1960), Dresh (1967), Ab’Saber (1969 a, b), Matsumoto (1974), Mabessone and Castro (1975), Mabessone (1978), Peulvast and Claudino Sales (2002), Valadão (2009), Maia et al (2010), among others.

Nevertheless, these theories, as well as part of the aforementioned research, discuss the role of the drainage network in the process of sculpting planation surfaces in a general way. However, such studies do not present the parameters to analyze this role, making generic observations on the work done by drainage networks. Hooke (2016) reminds us that flows in ephemeral channels are occasional, but the flooding can be devastating, requiring studies for a better understanding of the dynamics and variability of the geomorphic responses to such phenomena. Thus, it is necessary to develop case studies that demonstrate the performance of intermittent and ephemeral drainage channels in semiarid hydrographic basins (CAVALCANTE AND CUNHA, 2012) on an analytical scale that demonstrates the specific local conditions in the geomorphological evolution process.

In this context, the intention herein is to analyze the relationships between drainage networks and semiarid planated surfaces through a case study of the hydrographic basin of the Bom Sucesso River (Bahia state, Brazil) with a view to their contribution to the development of the local surface. Thus, the study sought to identify the planation levels, analyze the surface layers, describe the drainage channels, identify geomorphological compartments and evaluate the degree of dissection of the surface.

\section{THE GEOMORPHOLOGICAL CONTEXT OF THE STUDY AREA}

The local surface developed from the rocks that compose the Archean and Proterozoic terrains, part of the Serrinha Block, which is part of the structural domains of the Santaluz Complex and the Itapicuru Greenstone Belt in the basin (figure 1).

The Santaluz Complex (mid-lower Archean $>3.0 \mathrm{Ga}$ ) consists of banded gneisses, garnet and sillimanite and calcium silicate rocks, granodioritic orthogneisses with an augen texture, gneisses and migmatites and associated amphibolites (CPRM, 1989). Associated to these are gabbroic, peridotitic and dunitic basic/ultrabasic rocks. From a structural point of view, the complex is characterized by the occurrence of faults, fractures and a synformal axis (figure 1).

The Greenstone Belt of the Itapicuru River (lower Proterozoic 1.8 to $2.6 \mathrm{Ga}$ ) is grouped into three subunits. The sedimentary unit is composed of metapelites, metagraywackes and iron formations, meta-arkose, metagraywackes and metasiltstone; the structural lineaments have a preferential NW-SE orientation, followed subsequently by a S-NE orientation (CPRM, 1989). The felsic volcanic unit is composed of metandecites and metabacites (approximately $2.1 \mathrm{Ga}$ ) characterized by a fractured structure and shearing of the rocks, due to the tectonic force to which they were submitted (figure 1). The mafic volcanic unit consists of metagraywackes, metapelites and associated metacherts, in addition to the tholeiitic basalts with an approximate age of $2.2 \mathrm{Ga}$ (CPRM, 1989).

Ecological events, associated to climatic events, were responsible for a large part of the formation of the landscape that has the typical features of hot and dry environments (Dd' A' Semiarid, according to TORNTHWAITE and MATTHER - SEI, 1999). The high temperatures (average 24 ${ }^{\circ} \mathrm{C} /$ year) favor the mechanical breakdown of the granites which emerge on the surface and that comprise the inselbergs and raised surfaces (serras). The rainfall, scarce and poorly distributed throughout the year $(537.9 \mathrm{~mm}$ / year), occurs in a torrential regime and favors the transport of debris 
through diffuse superficial runoff, concentrated superficial runoff, and ephemeral and intermittent fluvial flow (LIMA; CUNHA AND PEREZ FILHO, 2013).

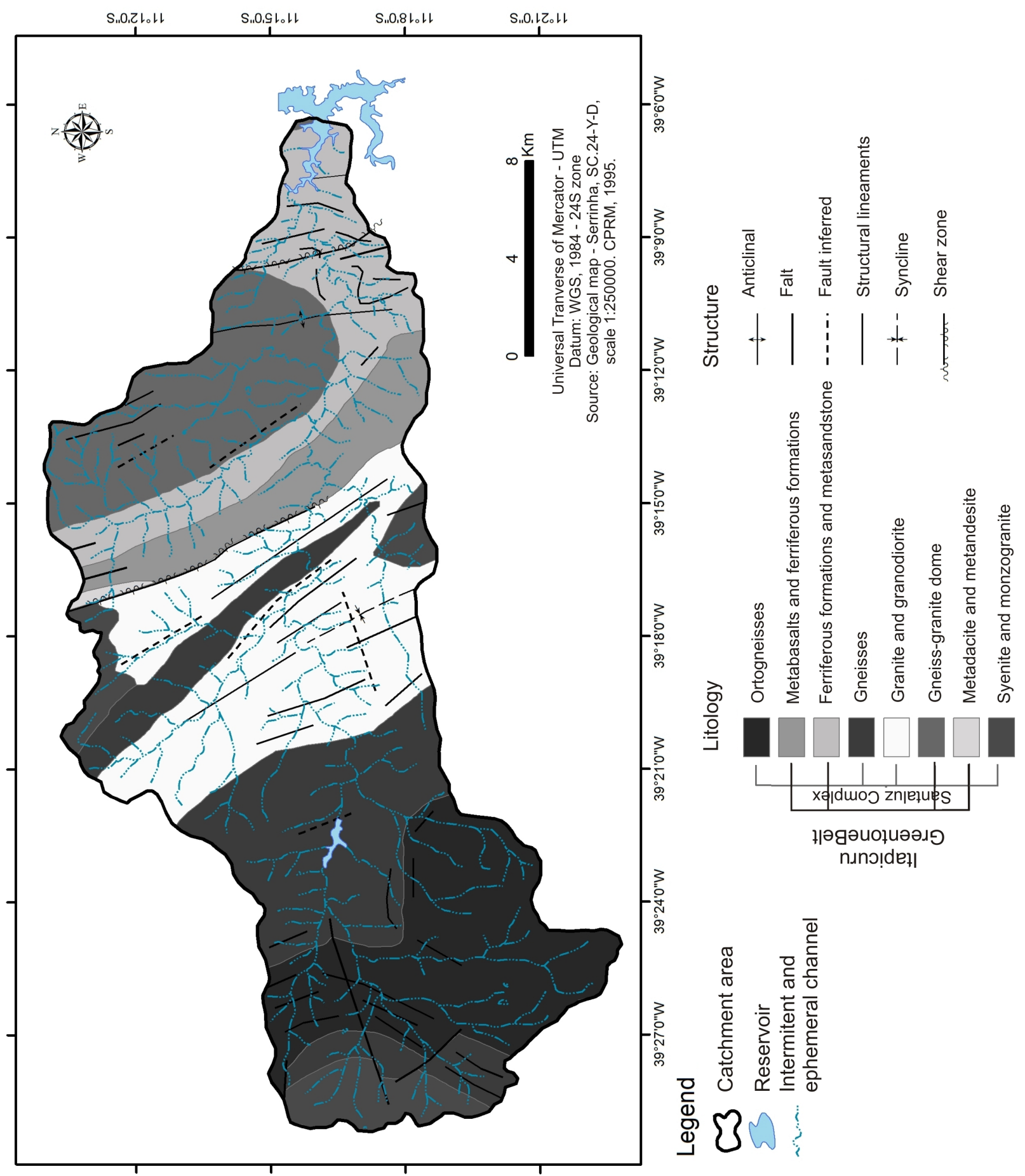

Figure 1 - A geological outline of the Hydrographic Basin of the Bom Sucesso River.

The semiarid conditions favor the creation of planation surfaces with inselbergs (Figure 2), through mechanisms and processes that demonstrate the dominion of the climate over the structure. These planation surfaces make up the sertanejo depression, characterized by degraded bare or buried surfaces and by retouched surfaces, also bare or buried (BRASIL, 1983). "In [the state] of Bahia, large planation surfaces are frequent and really characterize the landscape. They are well developed surfaces and become particularly clear in certain cases" (TRICART, 1958, p. 29). 


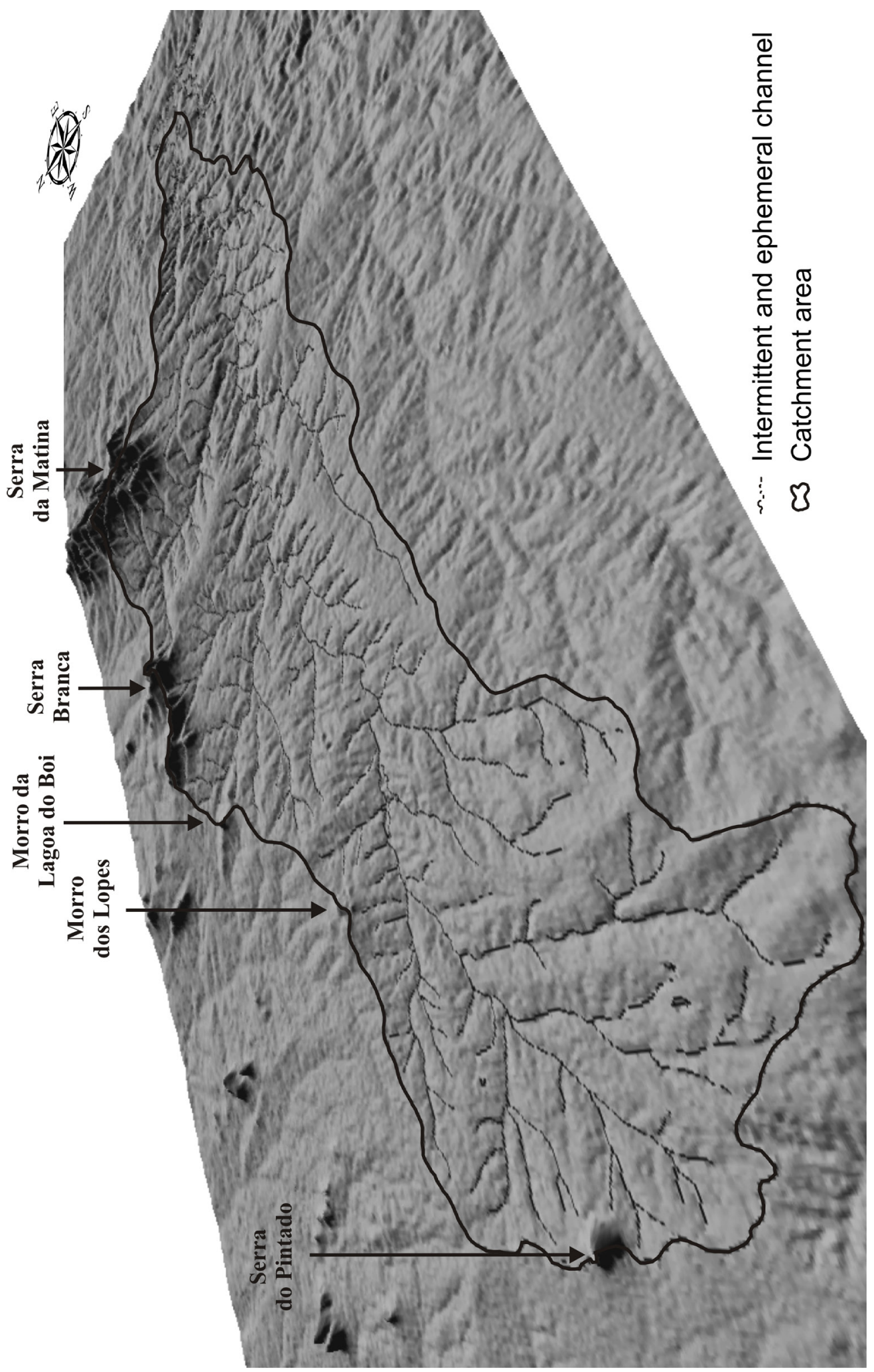

Figure 2 - A 3D visualization with a vertical amplification of the surface of the Hydrographic Basin of the Bom Sucesso River, showing areas of planation and residual elevations.

\section{METHODOLOGICAL PROCEDURES}

Bibliographies that deal with theories, concepts and case studies related to the geomorphological dynamics in the semiarid were analyzed. We also sought to base the research on a systemic method, taking into consideration the inherent complexity of the interdependent relations between 
the components of the system, which was evaluated as the most adequate method to analyze the phenomena in hydrographic basins (VICENTE AND PEREZ FILHO, 2003; MATTOS AND PEREZ FILHO, 2004; SANTOS, 2004; PEREZ FILHO AND QUARESMA, 2011).

During the internal studies, technical procedures were carried out to update the cartographic base focusing on the drainage channels and the geomorphological mapping on a scale of 1:100,000 (LIMA; CUNHA; PEREZ FILHO, 2013). Satellite products were used (raster images obtained from the CBERS 2B HRC, LandSat 5 TM and LandSat 7 ETM+ satellites; and a digital model of the SRTM terrain - Shuttle Radar Topography Mission) and processed by the Envi 4.5 software. The contrast, color contrast and filtering of the spatial frequencies were increased (CRÓSTA, 2002).

In addition, topographical profiles and thematic maps were created (geology, soils, slope, and hypsometry) and a morphometric analysis of the drainage network was carried out (CHRISTOFOLETTI, 1980), as well as the compartmentalization of the surface through adaptations of the proposal of the Brazilian Institute of Geography and Statistics (IBGE, 2009).

During the fieldwork, a survey was carried out of the characteristics of the fluvial channels related to the geometry and texture of the riverbed (MONTGOMERY AND BUFFINGTON, 1993) to identify the types of surface and geomorphological compartments mapped in the research laboratory. Representative samples of sediments deposited on the bed of the main channel were collected from four cross sections. Representative samples were also collected from the superficial formations on each planation level, according to the procedures of the Agricultural Institute of Campinas - IAC.

In the laboratory (Soil Physics Laboratory - IAC) an analysis was carried out of the granulometric properties of the samples of the superficial formations and the sediments from the riverbed. The Densimetry Method was used to define the fractions of coarse sand, fine sand, silt and clay.

\section{Results and discussion}

The geomorphological mapping and the fieldwork showed a generalized planation with an $\mathrm{E} \rightarrow \mathrm{W}$ decline, separated into three distinct topographical levels: upper, intermediate and lower, covered irregularly by the superficial layers (figure 3 ).

An analysis of the material covering the surface allows the assertion that the upper level (located in the eastern part of the basin with altitudes between 350 and 400 meters) is covered by sandy material originating from the granular breakdown of the leucocratic granites that compose the basement at this level. The representative sample for this level was collected at a depth of 0-15 cm and $15-30 \mathrm{~cm}$ and the granulometric analysis revealed a predominance of sand (coarse sand $41 \%$ and $40 \%$; fine sand $37 \%$ and $31 \%$ ) throughout the depth of the sample (figure 3 ). The production of the clay fraction is reduced $(10 \%$ and $13 \%)$ and the material is a grayish white color (hue 10 YR $9.5 / 1)$, which shows the absence of iron oxides (Fe) and the concentration of minerals such as quartz, feldspar, and calcite.

The intermediate level is located in the central part of the basin at altitudes between 300 and 350 meters. The material of the surface layer has a sandy texture (coarse sand $34 \%$ and fine sand $21 \%$ ), however, there is an increase in the silt portion (28\%) and a slight rise in the clay fraction $(18 \%)$ with respect to the upper planation level (figure 3). The representative sample was only analyzed at one depth $(0-15 \mathrm{~cm})$ because of the narrow thickness of the material that meant the material from the second depth $(15-17 \mathrm{~cm})$ was discarded. The color of the material was 2.5 Y 8.5 $/ 1$ indicating an increase in organic matter and iron oxides, quartz and mica, for example, derived from gneisses that comprise the basement at this level.

On the lower level (the west portion with altitudes between 250 and 300 meters) the superficial layers occur at incipient depths (figure 3). The depth of the sample was 0-12 cm due to contact with the basement. The textural analysis demonstrated the predominance of clay (78\%) to the detriment of the fraction of sand (coarse sand 5\% and fine sand 8\%) and the fraction of silt (9\%) (figure 1). The color of the material is brown-red (hue $2.5 \mathrm{Y} 7 / 2$ ) which denotes a concentration of iron oxides and the presence of organic matter in larger amounts in relation to other levels of planation. At 


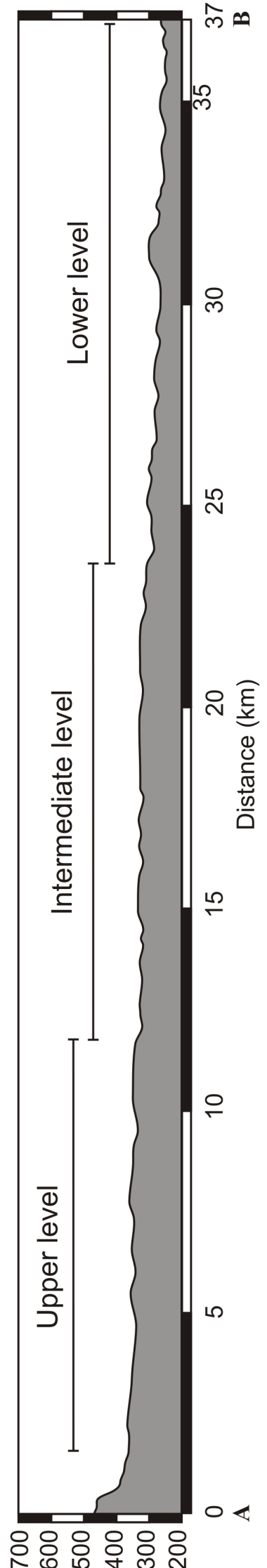

(w) 14 เाән

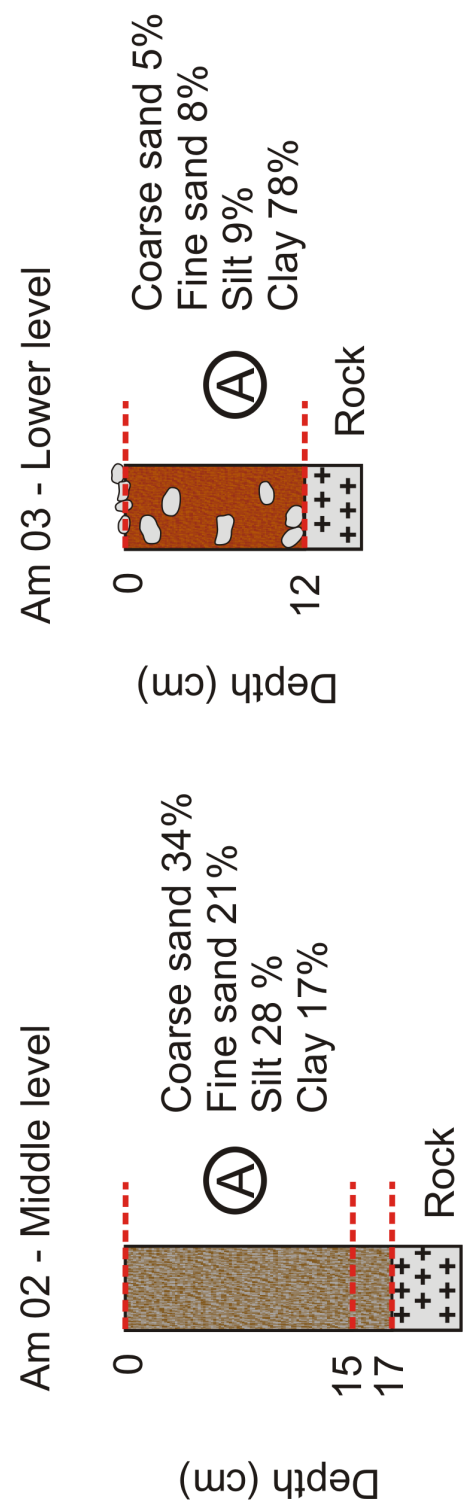

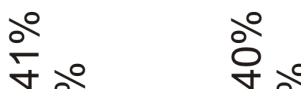

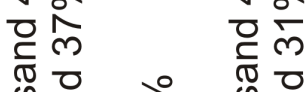

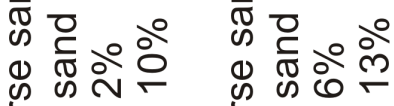
ब

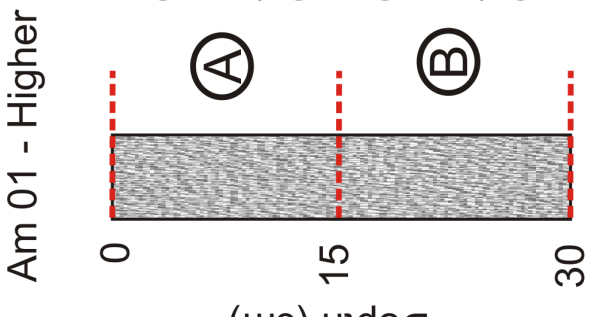

(แ०) पұdә0

Figure 3 - Topographical profile A-B of a representative stretch of the upper, intermediate and lower planation levels, with the respective textures of the superficial layers. 
the same time, there was a detrital pavement over the superficial formations and the occurrence of subsurface pebbles, mixed with clayey material (figure 3 ).

The basin's surface is covered by shallow superficial formations that consist of a sandy matrix, whose displacement processes carry the finer elements from upstream to downstream, which, in this case, correspond to the upper, intermediate and lower planations, respectively. The texture of the superficial formations indicates the importance of granular breakdown between weathering mechanisms. The production of fine elements is reduced and these are transported to the lower planation level by the water percolating in the sandy formations. Consequently, the amount of the clay fraction increases between the aforementioned samples.

According to Hooke (2016) the sensitivity of the channels to morphological changes is related to the size of the pellets they are formed of. Thus, in studies conducted in the semiarid region of Spain the author found that areas where coarse sediment predominates are less sensitive than those with finer ones.

In this case study, it was noted that the redistribution of material is limited in the upper pediments (one example is the abrupt change in the color of the superficial formations), whereas in the intermittent and ephemeral channels it is more expressive. Coarse material is deposited by the floods whilst fine materials are transported to the lower course and reach the lower planation level. The analysis of four cross sections distributed along the longitudinal profile of the Bom Sucesso River (figure 4) shows that, from upstream to downstream, the lateral erosion of the channel is intensified as it grows in fluvial hierarchy and receives contributions from other tributaries, even if they are intermittent and ephemeral channels.

The cross-section of section 1 (altitude $419 \mathrm{~m}$ ) has a first-order hierarchy and is $1.22 \mathrm{~m}$ width and $0.83 \mathrm{~m}$ deep (figure 4, 1a). The bottom of the channel has thin layer of sediment covered by angular pebbles, partly calibrated at size $>15 \mathrm{~cm}$ (figure $4,1 \mathrm{~b}$ ). The granulometric analysis of the sediments located below the pebble layer demonstrated a predominance of sand $(72 \%$ coarse sand and $13 \%$ fine sand) at the expense of fine sediments (silt $9 \%$ and clay $6 \%$ ) (figure $4,1 \mathrm{~b}$ ).

In cross section 2 (altitude $384 \mathrm{~m}$ ), the river has third-order hierarchy and is $3.51 \mathrm{~m}$ width and $1.20 \mathrm{~m}$ deep (figure 4, 2a). The channel has a sandy texture with angular, poorly calibrated pebbles (figure 4, 2a). The sandy portion represented $79 \%$ of the granulometry of the sample collected (coarse sand 58\% and fine sand 21\%); the other fractions represented $21 \%$ (silt $13 \%$ and clay $8 \%$ ).

In cross section 3 (altitude $320 \mathrm{~m}$ ) the channel has fourth-order hierarchy and is $3.98 \mathrm{~m}$ width and $1.32 \mathrm{~m}$ deep (Figure 4, 3a) with a flat bottom, the texture is predominantly clay loam (sand 42 $\%$, clay $40 \%$ silt and $18 \%$ ) and pebbles are absent (figure $4,3 \mathrm{~b}$ ).

Cross-section 4 is located in the lower course of the Bom Sucesso River at an altitude of 276 meters and has fifth-order hierarchy. At this point, the river is $7.87 \mathrm{~m}$ width and $3.07 \mathrm{~m}$ deep (Figure $4,4 \mathrm{a})$, the channel has a clay texture, as shown by the result of the granulometric analysis of the sample (53\% clay, $30 \%$ sand and silt $17 \%$ ) (figure $4,4 \mathrm{~b})$.

In studies of the Spanish semiarid region, Hooke (2006) verified that the shear stress, the flow potential and the transport capacity increase in accordance with the degree of the incision of the channel, producing more erosion. Considering that shallow channels have a lower shear stress, the result is a smaller transport capacity, which may partly justify the coarser material of first-order channels. However, as the same author points out, the real result is still highly dependent on the relations of the supply of sediments along the course.

The distribution of the sedimentary load along the Bom Sucesso River, as well as the morphometry of the channel and the granulometry of the sediments, suggest that the fluvial flow resulting from big pluviometric events is able to transport pebbles for short distances, which is why channels with a stony texture are associated with those of a first-order hierarchy. After more significant pluviometric events the torrential (high energy) fluvial flow becomes considered as low energy flow, with the transport of finer sediments over longer distances prevailing. 


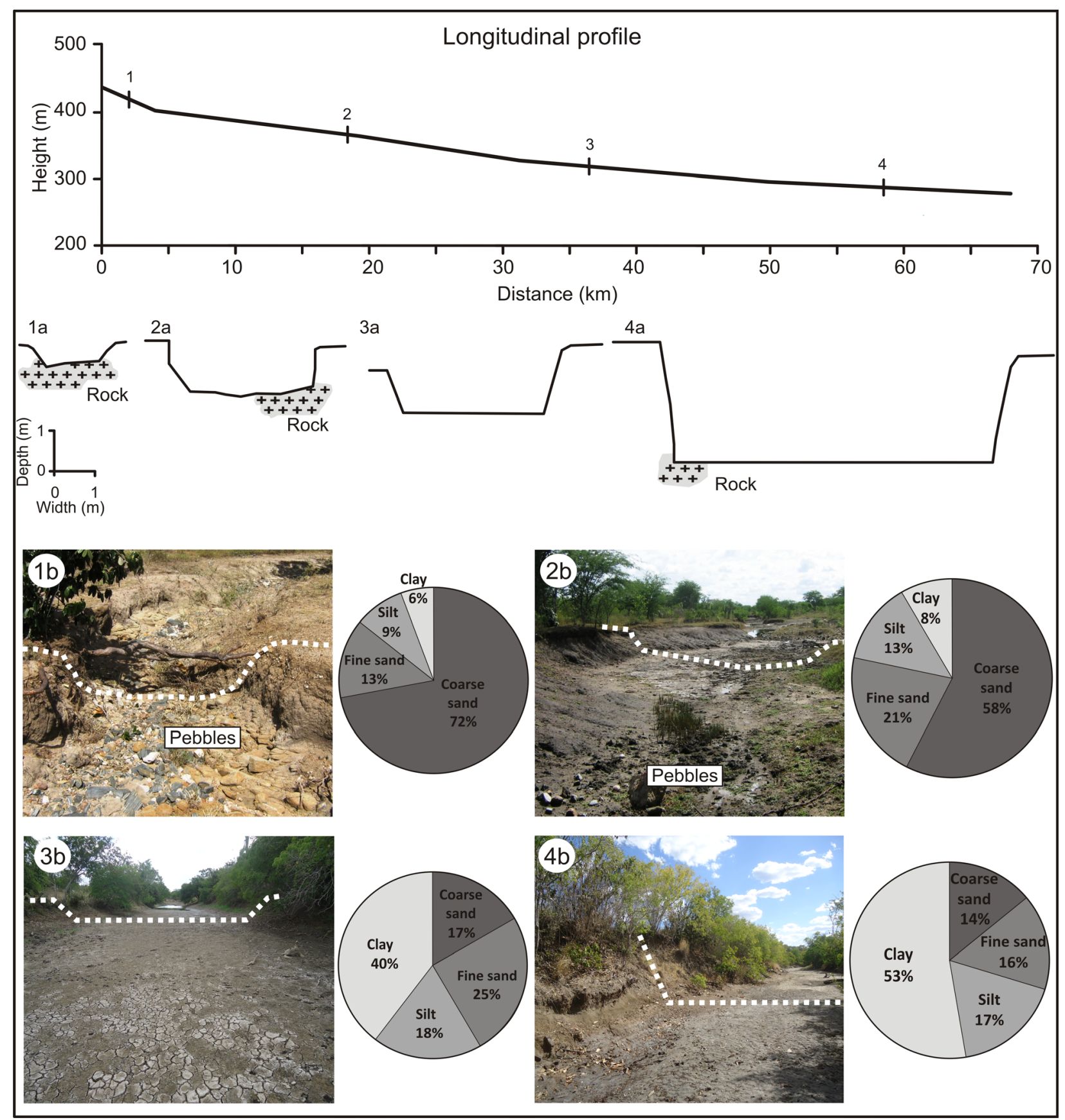

Figure 4 - Longitudinal profile of the Bom Sucesso River with transversal sections and the respective results of the granulometric analysis. Photographs taken in January 2011 and February 2012.

The role played by the floods caused by large-scale pluviometric events is fundamental for the transport and deposition of sediments to occur, which favors the development of forms of a fluvial genesis (SOUZA AND CORREAA, 2012), even on a small scale. These are examples of the forms of alluvial accumulation plains associated with low-order channels with ephemeral regimes, narrow and discontinuous flood plains and small fluvial terraces located along the Bom Sucesso River.

Hooke (2016) found that the behavior of the water flow is essential in altering the morphology of channels. Thus the frequency of the flow is an important factor, as are the characteristics of the material on the riverbed, as in his experimental studies some occurrences of floods did not cause any alteration in the morphology. Thus, it is a complex relationship that can vary within the same region, as in the case studied by the author.

The gradient of the main channel studied showed a slope value of $8.28 \%$ between the point 
of origin and the end point of its length, confirming the planated character of the surface. It also confirms that the main channel has a low potential for sediment mobilization, since the channel system itself does not allow a sufficient flow to maintain efficient transportation. Thus, only the fine material composed of clay and silt is moved.

The density of rivers, or hydrographic density, showed a value of 0.57 channels $/ \mathrm{km} 2$, in other words, there is a incidence of 0.57 drainage channels for each square kilometer of area, which is a low amount of channels ( 269 channels in a total area of $468 \mathrm{~km}^{2}$ ). Although the lithological and soil conditions favor the formation of a large number of rivers / streams due to the low permeability the rocks and the regolith, the rainfall does not favor the supply of the channels and reduces the basin's capacity to generate new channels.

The drainage density represents the degree of surface dissection and functions as a demonstrative index of the fluvial erosion of the surface. In this case, the drainage density was $0.92 \mathrm{~km} / \mathrm{km}^{2}$, that is, for each $\mathrm{km}^{2}$ area of basin there is a length or average extension of $0.92 \mathrm{~km}$ of drainage channel (433 km of channels draining a total area of $468 \mathrm{~km}^{2}$ of basin). According to this classification, the basin has a low drainage density, which contradicts the lithological and soil characteristics mentioned previously, since low drainage density values are associated with the substrate and permeable soils

Christofoletti (1980), states that when the drainage density is high, the infiltration is low because of the impermeability of the soils and rocks, which favors a higher drainage density. Thus, it is stated that the value of the drainage density $\left(0.92 \mathrm{~km} / \mathrm{km}^{2}\right)$ as well as the value of the river density $\left(0.57\right.$ channels $\left./ \mathrm{km}^{2}\right)$ are mainly associated with the characteristics of semiarid climates, although the lithological and soil conditions play an essential role in the frequency and extent of the channels. He also affirms that the low amount of drainage density indicates that the degree of general dissection of the surface is low.

The length of the superficial course was $460 \mathrm{~m}$, which means that the average distance covered by the superficial flow from the interfluves to the nearest drainage channel is 460 meters. This amount, along with the other morphometric values and the other characteristics pointed out above, demonstrate the gentle slope of the terrain, the small number of drainage channels and the low degree of dissection of the surface. Despite the low degree of dissection demonstrated by the drainage density, different forms of interaction between the drainage channels and the lithology, structure and soil, among other components of the basin, favor the different drainage patterns present in six geomorphological compartments, with different degrees of dissection (figure 5). 


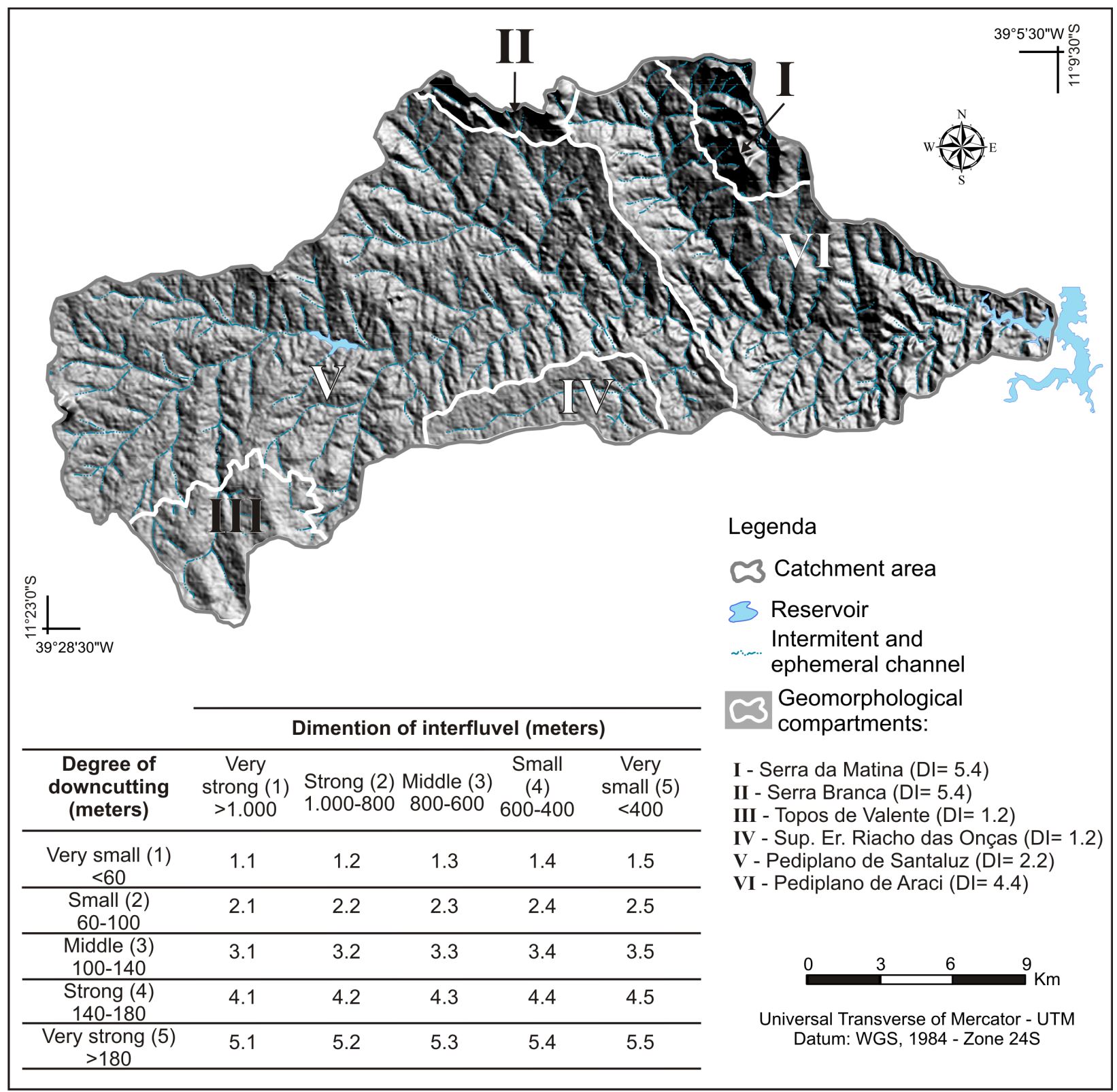

Figure 5 - The order of magnitude of the forms of dissection of the surface and the respective amounts of the dissection index (DI) of the geomorphological compartments.

The compartments with the highest dissection numbers (dissection index - DI) are those corresponding to the residual elevations (Serra Branca and Serra da Matina, both with a DI = 5.4) where the degree of downcutting of the drainage is very strong and the interfluve is small. Abrupt ridge lines predominate, a sequence of rectilinear or concave inclines and a V-shaped valley floor. The Araci pediplane, which is the lowest planation level, presented a DI $=4.4$ (a small interfluve and a strong degree of downcutting). The pediments are dissected by the action of the drainage, which in turn exploits the system of faults and fractures to excavate its bed. There are peaks with an average height of 260 meters, convex and concave slopes, and asymmetric V-shaped valleys associated with the first-order channels and flat-floored valleys in most of the compartment.

The compartment of the Santaluz pediplane corresponds to intermediate and upper levels of planation and had a DI $=2.2$, reflecting the large interfluve and the low degree of downcutting of the drainage channels. Flat interfluves with long gentle slopes and flat-floored valleys predominate. The compartments with lower dissection values correspond to the Erosion Surface of the Riacho das Onças and the Valente peaks (both DI =1.2). It was noted that the influence of the drainage on 
the dissection of the surface is insignificant on the surface of the Riacho das Onças, as confirmed by the large interfluve and the weak downcutting of the drainage. Conserved pediments, flat interfluves and shallow valleys with first and second-order channels predominate.

The Valente peaks are the compartment that most differentiate themselves from the others, as regards the forms of surface found in the semiarid. The drainage has lengthened channels of the first and second-order, located in flat-floored valleys with weakly incised alluvial plans. The alluvial plains consist of sandy sediments (predominant in this compartment), transported by superficial flow from the gently convex peaks and the long convex and concave slopes to the valley floors. It is considered that the spatial pattern of the drainage network and the geometry of the channels in this compartment are strongly influenced by the deep and sandy superficial layers that also favor the occurrence of long fluvial channels in a lesser amount.

Thus, it is possible to affirm that the different drainage patterns propitiate the organization of the geomorphological compartments which, in turn, have distinct erosion, transport and deposition patterns. The drainage network makes a significant contribution to the evolution process of the surface of the local planation, to the extent that the drainage favors the occurrence of different degrees of dissection of the planation levels (preserved and dissected). This fact is consistent with the work of Bezerra et al (2008), who studied the Cariatá region, stating that the regional landscape is being dissected by fluvial erosion or in ravines.

This situation is convergent with that reported by Coltorti, Dramis, Ollier (2007) in planated areas in the north of Ethiopia, in which the authors point out that the fluvial processes have had a prominent role in the genesis of planations, as demonstrated by the sedimentary facies of deposits found by these authors.

Pluviometric events of great magnitude are fundamentally important for the removal of sediment through river runoff in torrents and flooding. The results of these events are considered to be the main development agent of the depositional forms in the basin, as well as in the semiarid region (CORREA 2011). The discontinuous and irregular river flow contributes to the low potential to remove sediment from the system and the low potential to dissect the surface.

Therefore, the issues raised concerning the morphology of the surface of the Bom Sucesso hydrographic basin and its imbricated connection with the intermittent drainage network corroborates the ideas of Bezerra, et al (2008) on the regional geomorphological history, which according to the author, is more complicated than anticipated by the pediplanation model.

\section{FINAL CONSIDERATIONS}

The systemic relations between the components of the basin occur in a complex way, where it is considered that the trigger for the main geomorphological processes is the hot and dry climate, since the processes responsible for the development of landforms (especially those associated with surface planation) depend directly on climatic elements.

Nevertheless, the influence of geological factors (the lithology and structure) are evident in the spatial arrangement of the drainage network (MAIA AND BEZERRA, 2011; QUEIROZ NETO, 2011), since in many situations the rivers and streams take advantage of the system's faults and fractures to form their beds, leading to segments in which the change in the direction of the channels forms $90^{\circ}$ angles, with rectilinear traces.

Based on the analytical methods, it is affirmed that the degree of conservation of the planation levels is related to the performance of the drainage network, however, it cannot be said which factor(s) is (are) responsible for the creation of the different planation levels. Thus, the issue is whether only climate related or tectonic factors are responsible for the differentiation of the levels identified, according to the classical theories previously mentioned, or if a combination of elements of the two natures, as proposed by the new reflections on planated surfaces (PEULVAST AND CLAUDINO SALES, 2002; SALGADO, 2007; JAPSEN ET AL, 2009; MAIA, BEZERRA AND CLAUDINO 
SALES, 2010; SANTOS AND SALGADO, 2010), favoring the organization of local planation into three levels. These questionings can be answered through absolute dating methods of the correlated deposits and the superficial layers of the pediments, among other methods and techniques.

Moreover, we consider that the objectives proposed were reached, as the results obtained answered the issues raised, supported by the analytical method adopted and the methodological procedures performed, both considered satisfactory. This favors the replication of the procedures in other catchment areas in planated regions with semi-arid climates.

\section{BIBLIOGRAPHIC REFERENCE}

AB'SABER, A. N. Depressões periféricas e depressões semiáridas no nordeste do Brasil. Boletim Paulista de Geografia, São Paulo, v. 22, p. 3-18, 1956.

AB'SÁBER, A. N. Gênese das vertentes pendentes em inselbergs no Nordeste Brasileiro. Geomorfologia, São Paulo, v. 14, p. 6-8, 1969 (a).

AB'SÁBER, A. N. Participação das superfícies aplainadas nas paisagens do Nordeste Brasileiro. IGEOG-USP, Boletim de Geomorfologia, São Paulo, n. 19, 1969 (b).

BEZERRA, F.H.R.; NEVES, B.B.B.; CORRÊA, A.C.B.; BARRETO, A.M.F.; SUGUIO, K. Late Pleistocene tectonic-geomorphological development within a passive margin - The Cariatá trough, northeastern Brazil. Geomorphology, 97, p. 555-582, 2008.

BRASIL. Ministério das minas e energia. Secretaria-Geral. Projeto RADAMBRASIL, Folhas Aracaju/Recife (SC-24/25): geologia, geomorfologia, pedologia, vegetação, uso potencial da terra. Rio de Janeiro, 1983.

CAVALCANTE, A. A.; CUNHA, S. B. Morfodinâmica fluvial em áreas semiáridas: discutindo o vale do rio Jaguaribe - CE - Brasil. Revista Brasileira de Geomorfologia, v. 13, n.1, p. 39-49, 2012.

CHRISTOFOLETTI, A. Geomorfologia, São Paulo: Edgard Blücher, 1980.

COLTORTI, M.; DRAMIS, F.; OLLIER, C.D. Planation surfaces in northern Ethiopia. Geomorphology, 89, p. 287-296, 2007.

COMO retirar amostra de solo. Campinas: IAC online, 2012. Apresenta procedimentos de como retirar amostras de solo em campo. Disponível em: <http://www.iac.sp.gov.br/produtoseservicos/analisedosolo/ retiraramostrasolo.php>. Acesso em: janeiro de 2012.

CORRÊA, A. C. B. Antropogênese e morfogênese sob a ação de eventos climáticos de alta magnitude no semiárido pernambucano: o caso da bacia do riacho Salgado. Revista Brasileira de Geomorfologia, v. 12, n.3, p. 25-36, 2011.

CRÓSTA, A. P. Processamento digital de imagens de sensoriamento remoto. Campinas: IG/UNICAMP, 2002, 4. ed.

DEMANGEOT, J. Essai sur le relief du nord-est Brésilien. Annales de Géographie, v. 69, n.372, p. $157-$ 176, 1960. Disponível em: < http://www.persee.fr/web/revues/home/prescript/article/geo_0003-4010_1960_ num_69_372_14559>. Acesso em: outubro de 2010.

DRESCH. J. Les problémes morphologiques du Nord-Est brésilien. Bull. de l'Ass. de Géographes Français, 263/264, p. 48-59, 1967.

HOOKE, J.M. Morphological impacts of flow events of varying magnitude on ephemeral channels in a semiarid region. Geomorphology, 252, p. 128-143, 2016.

INSTITUTO BRASILEIRO DE GEOGRAFIA E ESTATISTICA (IBGE). Manual Técnico de Geomorfologia. Rio de Janeiro: IBGE, Coordenação de Recursos Naturais e Estudos Ambientais. 2. ed., 2009.

JAPSEN, P; BONOW, J.M.; GREEN, P.F.; CHALMERS, J.A.; LIDMAR-BERGSTRÖM. Formation, uplift and dissection of planation surfaces at passive continental margins - a new approach. Earth Surface Processes and Landforms, 34, p. 683-699, 2009.

KING, L. C. A geomorfologia do Brasil oriental. Revista brasileira de geografia, v. 18, n.2, p. 3-121, 1956. LIMA, K. C.; CUNHA, C. M. L.; PEREZ FILHO, A. Dificuldades e possibilidades da cartografia geomorfológica no semiárido brasileiro. Revista Brasileira de Cartografia, v. 65, n. 5, 2013. 
MABESSONE, J. M. Panorama geomorfológico do Nordeste Brasileiro. IGEOG-USP, Boletim de Geomorfologia, São Paulo, n. 56, 1978.

MABESOONE, J. M; CASTRO, C. Desenvolvimento geomorfológico do Nordeste Brasileiro. Boletim do Núcleo Nordeste da Sociedade Brasileira de Geologia, v. 3, p. 3-5, 1975.

MAIA, R. P.; BEZERRA, F. H. R. Neotectônica, geomorfologia e sistemas fluviais: Uma análise preliminar do contexto nordestino. Revista Brasileira de Geomorfologia, v. 12, n.3, p. 37-46, 2011.

MAIA, R. P.; BEZERRA, F. H. R; CLAUDINO SALES, V. Geomorfologia no Nordeste: concepções clássicas e atuais acerca das superfícies de aplainamento nordestinas. Revista de Geografia. Recife: UFPE - DCG/ NAPA, v. especial VIII SINAGEO, n. 1, p. 6-19, 2010.

MATSUMOTO, E. As formas de relevo e alguns problemas geomórficos na parte oriental do Nordeste Brasileiro. IGEOG-USP. Boletim de Geomorfologia, São Paulo, n. 44, 1974.

MATTOS, S. H. V. L.; PEREZ FILHO, A. Complexidade e estabilidade em sistemas geomorfológicos: uma introdução ao tema. Revista Brasileira de Geomorfologia, v. 5, n.1, p. 11-18, 2004.

MONTGOMERY, D. R.; BUFFINGTON, J. M. Channel classification, prediction of channel response and assessment of channel condition. Seattle: University of Washington, 1993.

PEREZ FILHO, A.; QUARESMA, C. C. Ação antrópica sobre as escalas temporais dos fenômenos geomorfológicos. Revista Brasileira de Geomorfologia, v. 12, n.3, p. 83-90, 2011.

PEULVAST, J. P.; CLAUDINO SALES, V. Aplainamento e geodinâmica: revisitando um problema clássico em geomorfologia. Mercator, v. 1, n. 1, p. 113-150, 2002.

QUEIROZ NETO, J. P. Relações entre as vertentes e os solos: Revisão de conceitos. Revista Brasileira de Geomorfologia, v. 12, n.3, p. 15-24, 2011.

RUELLAN, F. O papel das enxurradas na zona semi-árida brasileira. Noticia geomorfológica, Campinas, v. 2, n. 3, p.10-13, 1959.

SALGADO. A. A. R. Superfícies de aplainamento: antigos paradigmas revistos pela ótica dos novos conhecimentos geomorfológicos. Geografias. Belo Horizonte: UFMG, v. 03, n. 1, p. 64-78, 2007.

SANTOS, J. M. Na esteira da abordagem sistêmica. In: SANTOS, J. M.; FARIA, M. (org.) Reflexões e construções geográficas contemporâneas. Salvador: Ed. dos autores, 2004. p. 35-57.

SOUZA, J.O.P; CORRÊA, A.C.B. Sistema fluvial e planejamento local no semiárido. Mercator, Fortaleza, v. 11, n. 24, p. 149-168, 2012.

SANTOS, J. M.; SALGADO, A. A. R. Gênese da superfície erosiva em ambiente semiárido - Milagres/BA: considerações preliminares. Revista de Geografia. Recife: UFPE - DCG/NAPA, v. especial VIII SINAGEO, n. 1, p. 236-247, Set. 2010.

SERVIÇO GEOLÓGICO DO BRASIL (CPRM). Programa levantamentos geológicos básicos do Brasil. Carta geológica - Escala 1: 250.000 (Folha Serrinha SC.24-Y-D). 1989. Disponível em <www.cprm.br/ geobank>. Acesso em: outubro de 2010.

SUPERINTENDÊNCIA DE ESTUDOS ECONÔMICOS E SOCIAIS DA BAHIA (SEI). Balanço hídrico do estado da Bahia. Salvador: SEI, 1999.

TRICART, J. Alguns problemas geomorfológicos da Bahia. Noticia geomorfológica, Campinas, v. 1, n.2, p. 27-32, 1958.

VALADÃO, R. C. Geodinâmica de superfícies de aplanamento, desnudação continental e tectônica ativa como condicionantes da megageomorfologia do Brasil Oriental. Revista Brasileira de Geomorfologia, v.10, n.2, p. 77-90, 2009.

VICENTE, L. E.; PEREZ FILHO, A. Abordagem Sistêmica e Geografia. Geografia, Rio Claro, v. 28, n. 3 , p. 345-362, 2003.

Submitted february 2016 Accepted april 2016 
SILVA FILHO, L. A.; QUEIROZ, S. N.; CLEMENTINO, M. L. M. 